\title{
Effect of Different Fertilizer Packages on the Performance of Jhum Crops
}

\author{
T. K. Bala ${ }^{1}$, A. K. Paul ${ }^{1 *}$ and A. J. M. S. Karim ${ }^{2}$
}

${ }^{1}$ Dept. of Soil Science, Sher-e-Bangla Agricultural University, Dhaka (12 07), Bangladesh

${ }^{2}$ Dept. of Soil Science, Bangabandhu Sheikh Mujibur Rahaman Agricultural University, Gazipur (17 06), Bangladesh

\section{Article History}

Manuscript No. AR1645a

Received in $1^{\text {st }}$ August, 2016

Received in revised form $5^{\text {th }}$ October, 2016

Accepted in final form $7^{\text {th }}$ October, 2016

\section{Correspondence to}

${ }^{*} E$-mail: alokpaulsau@yahoo.com

\section{Keywords}

Jhum cultivation, fertilizer, crops

\begin{abstract}
An experiment was conducted at Hill Agricultural Research Station, Khagrachari, Bangladesh during May, 2014 to January, 2015 to study the effects of different fertilizer on the performance of jhum crops. Rice, marpha, maize, sweet gourd, sesame and arhar were used as the jhum test crops. The experiment was laid out in Latin Square Design (LSD). The treatments consisted of four levels of NPK fertilizers i.e. no fertilizer (Control), $40 \mathrm{~kg} \mathrm{~N}+25 \mathrm{~kg} \mathrm{P}_{2} \mathrm{O}_{5}+30 \mathrm{~kg} \mathrm{~K}_{2} \mathrm{O}$ ha' ${ }^{-1}, 80 \mathrm{~kg} \mathrm{~N}+50 \mathrm{~kg} \mathrm{P}_{2} \mathrm{O}_{5}+60 \mathrm{~kg}$ $\mathrm{K}_{2} \mathrm{O} \mathrm{ha}^{-1}$ and $120 \mathrm{~kg} \mathrm{~N}+75 \mathrm{~kg} \mathrm{P}_{2} \mathrm{O}_{5}+90 \mathrm{~kg} \mathrm{~K}_{2} \mathrm{O} \mathrm{ha}^{-1}$. The yield parameters and yields of jhum crops were significantly affected by fertilizer. NPK fertilizer plays a significant role on the yield of rice, marpha, maize, sesame, sweet gourd and arhar. The highest yield of rice $\left(3.34 \mathrm{t} \mathrm{ha}^{-1}\right)$, marpha $\left(984.8 \mathrm{~kg} \mathrm{ha}^{-1}\right)$, maize $\left(951.3 \mathrm{~kg} \mathrm{ha}^{-1}\right)$, sweet gourd (1418.0 kg ha-1), sesame $\left(331.3 \mathrm{~kg} \mathrm{ha}^{-1}\right)$ and arhar $\left(349.9 \mathrm{~kg} \mathrm{ha}^{-1}\right)$ were found in $\mathrm{T}_{4}$ treatment that received $120 \mathrm{~kg} \mathrm{~N}+75 \mathrm{~kg} \mathrm{P}_{2} \mathrm{O}_{5}+90 \mathrm{~kg} \mathrm{~K}_{2} \mathrm{O} \mathrm{ha}{ }^{-1}$. On the other hand, lowest yield of rice $\left(1.67 \mathrm{tha}^{-1}\right)$, marpha $\left(453.8 \mathrm{t} \mathrm{ha}^{-1}\right)$, maize $\left(517.5 \mathrm{t} \mathrm{ha}^{-1}\right)$, sweet gourd $\left(781.3 \mathrm{tha}^{-1}\right)$, sesame $\left(107.1 \mathrm{tha}^{-1}\right)$ and arhar $\left(103.6 \mathrm{tha}^{-1}\right)$ were found in the treatment with no fertilizer.
\end{abstract}

\section{Introduction}

Jhum cultivation is an age-old, rain-fed cultivation method, practiced by the indigenous people on the hills and slopes of the Chittagong Hill Tracts, because of the lack of flat land suitable for farming. This system involves cutting back and clearing large areas of the hillside through fire. Jhum cultivation also called slash and burn agriculture, shifting cultivation or swiddan cultivation.

This traditional cultivation practice has been the only way of subsistence agriculture practice for many of the CHT people specially who are living in remote places. It is estimated that about 40,000 households are engaged with jhum cultivation in CHT (Ullah et al., 2012). In the past, land was left fallow for between 15 to 20 years, which allowed the soil to regenerate its fertility. These days however population pressure, coupled with acute land scarcity has forced that time frame to be reduced to a rotation cycle of between 2 to 3 years (CARE, 2000).

Seeds of different crops are mixed together and sown in the field after the first rain shower (monsoon) has fallen, usually during the months of April to May. Typically, upland rice and vegetables are harvested within a few months after sowing, whereas cotton and arhar are harvested after 8 or 9 months, during December. Once the land becomes inadequate for crop production it is then left to be reclaimed by natural jungle vegetation once again, while the same activity continues elsewhere, with this cycle continually repeating itself rice is the most common crop in jhum farming and cultivated in rain fed condition.

Indigenous hill people are generally very poor, not enough educated and their livelihood depends mostly on wage earnings and jhum cultivation. CHT is completely different in physical features, agricultural practices and soil conditions from rest of the country. Food insecurity is a great concern in CHT where it is sometimes becomes very difficult to arrange three meals particularly for medium or big families. As the World food prices have hit the record highs recently and the uptrend is still continuing, the household of Chittagong Hill Tracts (CHTs) are highly vulnerable to food security due to their limited access to food. Now a day's, the shrinkage of jhum fields and reducing yields has created a challenge for the Jumia families. Compared to this low return from the jhum, still many of the people either partly or fully depend on jhum for their livelihoods (Borggaard et al., 2003). Degradation of upland soils is widespread in CHT and continues to accelerate due to gradual intensification of crop production without applying 
balanced fertilizers or manures (Miah et al., 2008).

Productivity of hill soil is constrained by erosion, no or little use of fertilizers, fertility depletion, strong soil acidity, inappropriate cropping and faulty management practices (Rasul and Thapa, 2002). These days it is gradually evolving and becoming more market oriented, which is also adding pressure for shorter land rotation. Ironically it seems possible fertilizer will become more and more necessary, and come to play an important role in this process, in stark contrast to the purely organic practice of the past. The depleted soil fertility is a major constraint to higher crop production in Chittagong Hill Tracts, Bangladesh (Farid et al., 2009). The increasing land use intensity has resulted in a great exhaustion of nutrients in soils. Continuous cultivation of this highly exhaustive cropping sequence in most of the lands has resulted in the decline of soil physico-chemical condition. For that reason scientists are trying to improve the production systems with the help of applications of fertilizer. The improvement of soil physicochemical properties by using fertilizers are supply for essential plant nutrient for higher yield. The applications of different fertilizer packages affect the yield, nutrient accumulation and quality of jhum crops.

Average rice yield was recorded $1.15 \mathrm{t} \mathrm{ha}^{-1}$ under Jhum cultivation (Uddin et al., 2010) which is much lower than national average of rice $\left(3.73 \mathrm{t} \mathrm{ha}^{-1}\right)$ (BBS, 2009). Rasul and Thapa (2002) reported that poverty is widespread in the CHT particularly in rural areas. Many rural families suffer from chronic food shortages. On average, per household per annum food (rice) shortage was found higher $(0.87 \mathrm{t})$ for non-ethnic and lower for ethnic households $(0.49 \mathrm{t})$ which constitutes $84.5 \%$ and $45.9 \%$ respectively (Uddin et al., 2010).

So, to restore the soil fertility and to increase the productivity of jhum, a judicious application of fertilizer is a must. Little or no research information on fertilizer management of jhum crops is available. Considering these facts as stated, the study was undertaken to develop a suitable dose of fertilizer for increasing the productivity of jhum crops.

\section{Materials and Methods}

An experiment was conducted at Hill Agricultural Research Station, Khagrachari Hill District in Chittagong Hill Tracts (CHT), Bangladesh under the Agro Ecological Zone of Northern and Eastern Hills. The morphological, physical and chemical characteristics of initial soils are presented in Tables 1 and 2.

\subsection{Land preparation}

The selected land was slashed and burned and partially burnt plant parts were cleaned during land preparation and no tillage was given. All kinds of weeds and residues were removed from the field.

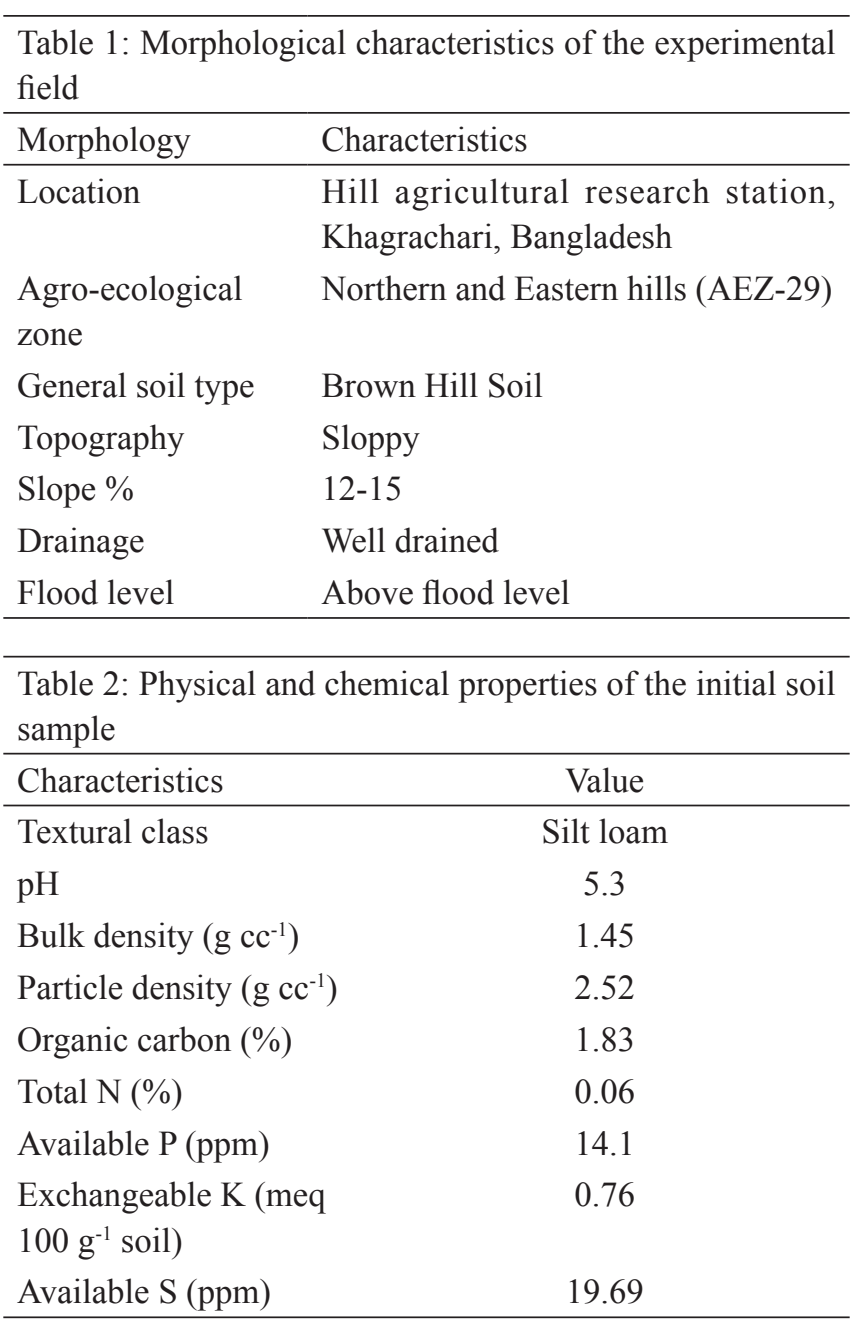

\subsection{Experimental design}

The experiment was designed in Latin Square Design (LSD)

\subsection{Test crops}

Rice, marpha (cucumber), maize, sweet gourd, sesame and arhar were used as the jhum test crop. Locally available varieties were used for all the crops.

\subsection{Seed sowing}

Seeds are sown by dibbling method with the help of $D a$. Seeds are sown directly on the soil. Before sowing, seeds of different jhum crops except sesame were mixed together. The seed mixture of rice to other crops was 100:1 i.e. rice cover major portion of the land. Sesame seed was broadcasted over the soil surface after sowing of rice and other crops seed mixture. Treatments

There were 4 treatment combinations. The treatment combinations were as follows:

$\mathrm{T}_{1}$ : No fertilizer (Control)

$\mathrm{T}_{2}: 40 \mathrm{~kg} \mathrm{~N}+25 \mathrm{~kg} \mathrm{P}_{2} \mathrm{O}_{5}+30 \mathrm{~kg} \mathrm{~K}_{2} \mathrm{O} \mathrm{ha}^{-1}$

$\mathrm{T}_{3}: 80 \mathrm{~kg} \mathrm{~N}+50 \mathrm{~kg} \mathrm{P}_{2} \mathrm{O}_{5}+60 \mathrm{~kg} \mathrm{~K}_{2} \mathrm{O} \mathrm{ha}^{-1}$

$\mathrm{T}_{4}: 120 \mathrm{~kg} \mathrm{~N}+75 \mathrm{~kg} \mathrm{P}_{2} \mathrm{O}_{5}+90 \mathrm{~kg} \mathrm{~K}_{2} \mathrm{O} \mathrm{ha}^{-1}$ 


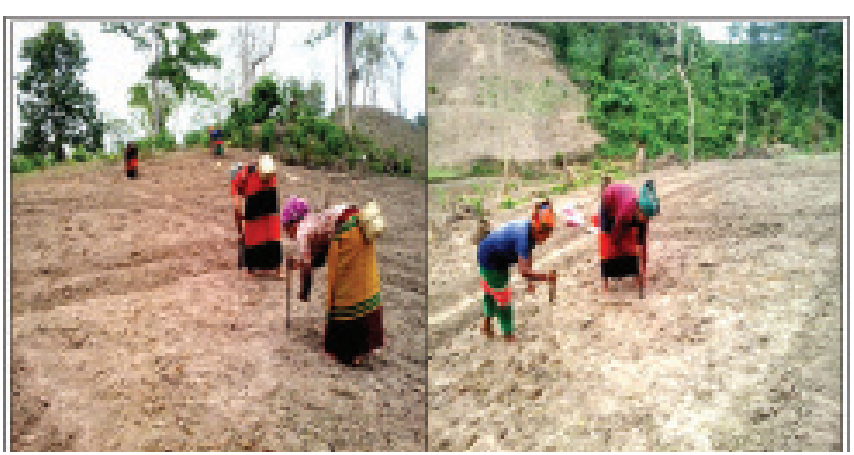

Figure 1: Seed sowing in jhum cultivation

\subsection{Application of fertilizers}

Urea, TSP and MoP were used as a source of N, P and K respectively. The amounts of nitrogen, phosphorus and potassium fertilizers required plot $^{-1}$ were calculated. Half urea and full amount of TSP and MoP were applied at the time of final land preparation by dibbling method. Rest of the urea was top dressed in two splits-one at vegetative and another at maximum tillering stage of rice.

\subsection{Intercultural operations}

The following intercultural operations were done for ensuring the normal growth of the crop. Top dressing of urea was done as per schedule and the normal cultural practices including weeding and insecticides spray were done as and when necessary. The crop was infested with some common weeds and controlled by uprooting. There were some incidence of insect attack specially rice hispa and rice stem borer, which were controlled by spraying Diazinon and Malathion. Disease i.e. brown spot of rice was controlled by spraying Filia @ 2 $\mathrm{ml} \mathrm{l}^{-1}$.

\subsection{Plant sampling at harvest}

Plants from $1 \mathrm{~m}^{2}$ were randomly selected from each plot to record the yield of rice, marpha, maize, sesame, sweet gourd and arhar. The selected hills were collected before harvesting. Yields of all crops were recorded plot-wise and expressed at t ha ${ }^{-1}$ on sundry basis.

\subsection{Harvesting}

The crop was harvested at maturity. Harvesting of Marpha was done on $4^{\text {th }}$ August, 2014, Maize on $9^{\text {th }}$ August, 2014, Sweet Gourd on $18^{\text {th }}$ August, 2014. Harvesting of rice was done on $19^{\text {th }}$ September, 2014. In case of Arhar harvesting was done on $15^{\text {th }}$ January, 2015. The harvested crop was threshed plot-wise. Grain yields of all crops and straw yields of rice were recorded separately plot-wise and after sun drying weight carefully.

\subsection{Statistical analysis}

The statistical analyses for different characters of jhum crops were done following the MSTAT-C statistical package and the mean results in case of significant F-values were adjusted by the Least Significant Difference (LSD) (Gomez et al., 1984).

\section{Results and Discussion}

The experiment was conducted to study the effect of different fertilizers (NPK) on the growth and yield of jhum crops. The results are presented and discussed under the following parameters.

\subsection{Yield of jhum rice}

\subsubsection{Grain yield}

The grain yield of jhum rice varied significantly due to application of different rates of NPK fertilizer treatments (Table 3). The grain yield ranged from 1.67 to $3.34 \mathrm{t} \mathrm{ha}^{-1}$. The highest grain yield $\left(3.34 \mathrm{t} \mathrm{ha}^{-1}\right)$ was found in $\mathrm{T}_{4}$ treatment receiving $120 \mathrm{~kg} \mathrm{~N}+75 \mathrm{~kg} \mathrm{P}_{2} \mathrm{O}_{5}+90 \mathrm{~kg} \mathrm{~K}_{2} \mathrm{O} \mathrm{ha}{ }^{-1}$. The lowest yield (1.67 t ha-1) was recorded in $\mathrm{T}_{1}$ (control) treatment. Second highest yield $\left(2.93 \mathrm{tha}^{-1}\right)$ was found in $\mathrm{T}_{3}$ treatment receiving $80 \mathrm{~kg} \mathrm{~N}+50 \mathrm{~kg} \mathrm{P}_{2} \mathrm{O}_{5}+60 \mathrm{~kg} \mathrm{~K}_{2} \mathrm{O} \mathrm{ha}^{-1}$. The treatments may be ranked in the order of $\mathrm{T}_{4}>\mathrm{T}_{3}>\mathrm{T}_{2}>\mathrm{T}_{1}$ with respect of grain yield. Satyanarayana et al. (2010) reported that grain yield increase significantly due to application of NPK fertilizers. Nyalemegbe et al. (2009); Islam et al. (2010) also cited that increase rate of NPK fertilizer will increase the yield of rice significantly.

\subsubsection{Straw yield}

Straw yield of $j$ hum rice also varied significantly at different levels of fertilizer treatments under study (Table 3). The yields of straw ranged from 2.45 to $4.18 \mathrm{t} \mathrm{ha}^{-1}$. The highest straw yield $\left(4.18 \mathrm{tha}^{-1}\right)$ was obtained in $\mathrm{T}_{4}$ treatment received $120 \mathrm{~kg} \mathrm{~N}+75 \mathrm{~kg} \mathrm{P}_{2} \mathrm{O}_{5}+90 \mathrm{~kg} \mathrm{~K}_{2} \mathrm{O} \mathrm{ha}^{-1}$ which was statistically differed with all other treatments. The lowest straw yield $\left(2.45 \mathrm{t} \mathrm{ha}^{-1}\right)$ was noted in $\mathrm{T}_{1}$ (control) treatment. The treatment may be ranked in the order of $\mathrm{T}_{4}>\mathrm{T}_{3}>\mathrm{T}_{2}>\mathrm{T}_{1}$ in terms of

Table 3: Effect of NPK fertilizers on the grain and straw yields $\left(\mathrm{t} \mathrm{ha}^{-1}\right)$ of jhum rice

\begin{tabular}{lcc}
\hline Treatment $^{*}$ & Grain yield $\left(\mathrm{t} \mathrm{ha}^{-1}\right)$ & Straw yield $\left(\mathrm{t} \mathrm{ha}^{-1}\right)$ \\
$\mathrm{T}_{1}$ & $1.67^{\mathrm{d}}$ & $2.45^{\mathrm{d}}$ \\
$\mathrm{T}_{2}$ & $2.48^{\mathrm{c}}$ & $2.78^{\mathrm{c}}$ \\
$\mathrm{T}_{3}$ & $2.93^{\mathrm{b}}$ & $3.69^{\mathrm{b}}$ \\
$\mathrm{T}_{4}$ & $3.34^{\mathrm{a}}$ & $4.18^{\mathrm{a}}$ \\
$\mathrm{LSD}(p=0.01)$ & 0.22 & 0.29 \\
\hline
\end{tabular}

Means in a column followed by same letter (s) are not significantly different at $1 \%$ level of significance by LSD;

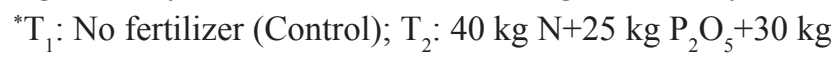
$\mathrm{K}_{2} \mathrm{O} \mathrm{ha}^{-1} ; \mathrm{T}_{3}: 80 \mathrm{~kg} \mathrm{~N}+50 \mathrm{~kg} \mathrm{P}_{2} \mathrm{O}_{5}+60 \mathrm{~kg} \mathrm{~K}_{2} \mathrm{O} \mathrm{ha}^{-1} ; \mathrm{T}_{4}: 120$ $\mathrm{kg} \mathrm{N}+75 \mathrm{~kg} \mathrm{P}_{2} \mathrm{O}_{5}+90 \mathrm{~kg} \mathrm{~K}_{2} \mathrm{O} \mathrm{ha}^{-1}$ 
straw yield. Ravi et al. (2007) reported that the straw yield increasesignificantly due to application of NPK fertilizers. Nyalemegbe et al. (2009) also found the same results in case of straw yield of rice.

\subsection{Yield of jhum crops other than rice}

Jhumia farmers' use rice as a major crops and use other crops in minor amount. Seeds of different crops are mixed together and sown. The ratio of seed mixture (rice:other crop) is 100: 1 i.e. rice cover $95 \%$ of the total land area and other crops cover $5 \%$ of rest of the land. Yield of jhum crops other than rice got from that $5 \%$ are represented here.

\subsubsection{Yield of marpha}

Different levels of NPK fertilizer showed statistically significant variation on fruit yield of marpha (Table 4). The maximum yield $\left(984.8 \mathrm{~kg} \mathrm{ha}^{-1}\right)$ was recorded from $\mathrm{T}_{4}$ treatment that received $120 \mathrm{~kg} \mathrm{~N}+75 \mathrm{~kg} \mathrm{P}_{2} \mathrm{O}_{5}+90 \mathrm{~kg} \mathrm{~K}_{2} \mathrm{O} \mathrm{ha}^{-1}$ which was highly significant than other treatments. Second highest yield $683.5 \mathrm{~kg} \mathrm{ha}^{-1}$ was recorded from $\mathrm{T}_{3}$ treatment receiving $80 \mathrm{~kg} \mathrm{~N}+50 \mathrm{~kg} \mathrm{P}_{2} \mathrm{O}_{5}+60 \mathrm{~kg} \mathrm{~K}_{2} \mathrm{O} \mathrm{ha}^{-1}$. The lowest yield $\left(453.8 \mathrm{~kg} \mathrm{ha}^{-1}\right)$ was observed in $\mathrm{T}_{1}$ treatment received no fertilizer. The treatment may be ranked in the order of $\mathrm{T}_{4}>\mathrm{T}_{3}>\mathrm{T}_{2}>\mathrm{T}_{1}$ in terms of marpha yield. Ravikumar (2009) found highest fruit yield of cucumber with the application of 120:70:90 kg NPK ha-1. Ubeiz (2009); Abdel-Mawgoud et al. (2005) reported that NPK fertilizer have a positive response in the vegetative growth and increasedyield of cucumber.

\subsubsection{Yield of maize}

The grain yield of maize was significantly influenced by different levels of NPK fertilizer (Table 4). The yields of maize ranged from 517.5 to $951.3 \mathrm{~kg} \mathrm{ha}^{-1}$. The highest maize yield $\left(951.3 \mathrm{~kg} \mathrm{ha}^{-1}\right)$ was obtained from $\mathrm{T}_{4}$ treatment that

Table 4: Effect of NPK fertilizers on the yields $\left(\mathrm{kg} \mathrm{ha}^{-1}\right)$ of marpha, maize, sweet gourd, sesame and arhar

\begin{tabular}{lccccc}
\hline $\begin{array}{l}\text { Treat- } \\
\text { ments }\end{array}$ & $\begin{array}{c}\text { Marpha } \\
\left(\mathrm{kg} \mathrm{ha}^{-1}\right)\end{array}$ & $\begin{array}{c}\text { Maize } \\
\left(\mathrm{kg} \mathrm{ha}^{-1}\right)\end{array}$ & $\begin{array}{c}\text { Sweet } \\
\text { gourd } \\
\left(\mathrm{kg} \mathrm{ha}^{-1}\right)\end{array}$ & $\begin{array}{c}\text { Sesame } \\
\left(\mathrm{kg} \mathrm{ha}^{-1}\right)\end{array}$ & $\begin{array}{c}\text { Arhar } \\
\left(\mathrm{kg} \mathrm{ha}^{-1}\right)\end{array}$ \\
\hline $\mathrm{T}_{1}$ & $453.8^{\mathrm{d}}$ & $517.5^{\mathrm{c}}$ & $781.3^{\mathrm{d}}$ & $107.1^{\mathrm{c}}$ & $103.6^{\mathrm{c}}$ \\
$\mathrm{T}_{2}$ & $502.5^{\mathrm{c}}$ & $749.3^{\mathrm{b}}$ & $1033.0^{\mathrm{c}}$ & $241.4^{\mathrm{b}}$ & $275.9^{\mathrm{b}}$ \\
$\mathrm{T}_{3}$ & $683.5^{\mathrm{b}}$ & $751.0^{\mathrm{b}}$ & $1113.0^{\mathrm{b}}$ & $245.4^{\mathrm{b}}$ & $277.7^{\mathrm{b}}$ \\
$\mathrm{T}_{4}$ & $984.8^{\mathrm{a}}$ & $951.3^{\mathrm{a}}$ & $1418.0^{\mathrm{a}}$ & $331.3^{\mathrm{a}}$ & $349.9^{\mathrm{a}}$ \\
$\mathrm{LSD}$ & 52.40 & 22.66 & 30.79 & 7.15 & 12.62 \\
$(p=0.05)$ & & & & & \\
\hline
\end{tabular}

Means in a column followed by same letter (s) are not significantly different at $5 \%$ level of significance by LSD; ${ }^{*} \mathrm{~T}_{1}$ : No fertilizer (Control); $\mathrm{T}_{2}: 40 \mathrm{~kg} \mathrm{~N}+25 \mathrm{~kg} \mathrm{P}_{2} \mathrm{O}_{5}+30 \mathrm{~kg} \mathrm{~K}_{2} \mathrm{O} \mathrm{ha}^{-1}$; $\mathrm{T}_{3}: 80 \mathrm{~kg} \mathrm{~N}+50 \mathrm{~kg} \mathrm{P}_{2} \mathrm{O}_{5}+60 \mathrm{~kg} \mathrm{~K}_{2} \mathrm{O} \mathrm{ha}^{-1} ; \mathrm{T}_{4}: 120 \mathrm{~kg} \mathrm{~N}+75 \mathrm{~kg}$ $\mathrm{P}_{2} \mathrm{O}_{5}+90 \mathrm{~kg} \mathrm{~K}_{2} \mathrm{O}$ ha $^{-1}$ received $120 \mathrm{~kg} \mathrm{~N}+75 \mathrm{~kg} \mathrm{P}_{2} \mathrm{O}_{5}+90 \mathrm{~kg} \mathrm{~K}_{2} \mathrm{O}$ ha $^{-1}$ which was statistically differed with other treatments. The lowest maize yield $\left(517.5 \mathrm{~kg} \mathrm{ha}^{-1}\right)$ was recorded in $\mathrm{T}_{1}$ (control) treatment with no fertilizer application. Second highest maize yield $\left(751.0 \mathrm{~kg} \mathrm{ha}^{-1}\right)$ was found in $\mathrm{T}_{3}$ treatment $(80 \mathrm{~kg} \mathrm{~N}+50 \mathrm{~kg}$ $\mathrm{P}_{2} \mathrm{O}_{5}+60 \mathrm{~kg} \mathrm{~K}_{2} \mathrm{O} \mathrm{ha}^{-1}$ ) which was statistically identical with $\mathrm{T}_{2}$ treatment $\left(40 \mathrm{~kg} \mathrm{~N}+25 \mathrm{~kg} \mathrm{P}_{2} \mathrm{O}_{5}+30 \mathrm{~kg} \mathrm{~K}_{2} \mathrm{O} \mathrm{ha}^{-1}\right)$. The treatment may be ranked in the order of $\mathrm{T}_{4}>\mathrm{T}_{3}>\mathrm{T}_{2}>\mathrm{T}_{1}$ in terms of maize yield. Halim et al. (2004) found that maize yield increased with combined application of NPK fertilizer. Talukder et al. (2011) reported that increase rates of $\mathrm{P}$ and/or $\mathrm{K}$ will increased seed protein and grain yield of maize with $120 \mathrm{~N} \mathrm{~kg} \mathrm{ha}^{-1}$ as a basal dose.

\subsubsection{Yield of sweet gourd}

NPK fertilizer increases the yield of sweet gourd significantly. Different levels of NPK fertilizer management showed significant variation on yield of sweet gourd (Table 4). The maximum yield of sweet gourd $\left(1418.0 \mathrm{~kg} \mathrm{ha}^{-1}\right)$ was recorded in $\mathrm{T}_{4}$ treatment that received $120 \mathrm{~kg} \mathrm{~N}+75 \mathrm{~kg} \mathrm{P}_{2} \mathrm{O}_{5}+90 \mathrm{~kg}$ $\mathrm{K}_{2} \mathrm{O} \mathrm{ha}^{-1}$. The lowest yield $\left(781.30 \mathrm{~kg} \mathrm{ha}^{-1}\right)$ was recorded in $\mathrm{T}_{1}$ treatment where no fertilizer was used. The treatment may be ranked in the order of $\mathrm{T}_{4}>\mathrm{T}_{3}>\mathrm{T}_{2}>\mathrm{T}_{1}$ in terms of sweet gourd yield. Makal et al. (2007) and Nmanop (1997) reported that the combined applicationof NPK fertilizers increase the fruit yield of sweet gourd significantly. Alom (2005) found that application of NPK at the rate of 120-70-90 $\mathrm{kg} \mathrm{ha}^{-1}$ produced the highest yield of sweet gourd.

\subsubsection{Yield of sesame}

The NPK fertilizer plays a significant role on the seed yield of sesame (Sesamum indicum). The seed yield of sesame was significantly influenced by different levels of NPK fertilizer (Table 4). The yield ranged from 107.1 to 331.3 $\mathrm{kg} \mathrm{ha}^{-1}$. The highest yield $\left(331.3 \mathrm{~kg} \mathrm{ha}^{-1}\right)$ was found in $\mathrm{T}_{4}$ treatment received $120 \mathrm{~kg} \mathrm{~N}+75 \mathrm{~kg} \mathrm{P}_{2} \mathrm{O}_{5}+90 \mathrm{~kg} \mathrm{~K}_{2} \mathrm{O}$ ha $^{-1}$. The lowest yield (107.1 $\left.\mathrm{kg} \mathrm{ha}^{-1}\right)$ was recorded in $\mathrm{T}_{1}$ (control) treatment. Second highest yield $\left(245.4 \mathrm{~kg} \mathrm{ha}^{-1}\right)$ was found in $\mathrm{T}_{3}$ treatment with $80 \mathrm{~kg} \mathrm{~N}+50 \mathrm{~kg} \mathrm{P}_{2} \mathrm{O}_{5}+60 \mathrm{~kg} \mathrm{~K}_{2} \mathrm{O} \mathrm{ha}^{-1}$ which was statistically similar with $\mathrm{T}_{2}$ treatment received $40 \mathrm{~kg}$ $\mathrm{N}+25 \mathrm{~kg} \mathrm{P}_{2} \mathrm{O}_{5}+30 \mathrm{~kg} \mathrm{~K}_{2} \mathrm{O} \mathrm{ha}^{-1}$. Sandabe el al. (2011) found that optimum number of capsule and seed yield was obtained with the combined application of NPK fertilizer@120:75:90 $\mathrm{kg} \mathrm{ha}^{-1}$.

\subsubsection{Yield of arhar (pigeon pea)}

Different levels of NPK fertilizer showed statistically significant variation on the yield of arhar (Table 4). The yield of arhar ranged from 103.6 to $349.9 \mathrm{~kg} \mathrm{ha}^{-1}$. The highest yield (349.9 $\mathrm{kg} \mathrm{ha}^{-1}$ ) was recorded from $\mathrm{T}_{4}$ treatment that received $120 \mathrm{~kg} \mathrm{~N}+75 \mathrm{~kg} \mathrm{P}_{2} \mathrm{O}_{5}+90 \mathrm{~kg} \mathrm{~K}_{2} \mathrm{O} \mathrm{ha}^{-1}$. Second highest yield $\left(277.7 \mathrm{~kg} \mathrm{ha}^{-1}\right)$ was recorded from $\mathrm{T}_{3}$ treatment with 80 
$\mathrm{kg} \mathrm{N}+50 \mathrm{~kg} \mathrm{P}_{2} \mathrm{O}_{5}+60 \mathrm{~kg} \mathrm{~K}_{2} \mathrm{O}$ ha $^{-1}$ which was statistically identical with $\mathrm{T}_{2}$ treatment received $40 \mathrm{~kg} \mathrm{~N}+25 \mathrm{~kg} \mathrm{P}_{2} \mathrm{O}_{5}+30$ $\mathrm{kg} \mathrm{K}_{2} \mathrm{O} \mathrm{ha}^{-1}$. The lowest yield (103.6 $\left.\mathrm{kg} \mathrm{ha}^{-1}\right)$ was observed in $\mathrm{T}_{1}$ treatment receiving no fertilizer. The treatment may be ranked in the order of $\mathrm{T}_{4}>\mathrm{T}_{3}>\mathrm{T}_{2}>\mathrm{T}_{1}$ in terms of arhar yield. Pachauri et al. (2008) reported that NPK fertilizer increase the yield of pigeon pea significantly. Kushwaha (2001) cited that application of $90 \mathrm{~kg} \mathrm{~K}_{2} \mathrm{O} \mathrm{ha}^{-1}$ increase the use efficiency of $\mathrm{K}$ and increase the yield of pigeon pea.

\subsection{Nutrient content in post-harvest soil}

\subsection{1. $\mathrm{pH}$}

Variation was recorded in post-harvest soil $\mathrm{pH}$ due to the application of different levels of NPK fertilizer in jhum cultivation (Table 5). The highest $\mathrm{pH}$ of post-harvest soil (5.25) was found from $\mathrm{T}_{4}$ treatment that received $120 \mathrm{~kg}$ $\mathrm{N}+75 \mathrm{~kg} \mathrm{P}_{2} \mathrm{O}_{5}+90 \mathrm{~kg} \mathrm{~K}_{2} \mathrm{O}_{\text {ha }}{ }^{-1}$. The lowest $\mathrm{pH}$ in post-harvest soil (5.15) was recorded from $\mathrm{T}_{1}$ treatment receiving no fertilizers.

\subsubsection{Organic matter}

Organic matter in post-harvest soil was varied with different levels of NPK fertilizer for jhum cultivation (Table 5). The highest organic matter in post-harvest soil $(3.05 \%)$ was recorded from $\mathrm{T}_{4}$ treatment which received $120 \mathrm{~kg} \mathrm{~N}+75 \mathrm{~kg}$ $\mathrm{P}_{2} \mathrm{O}_{5}+90 \mathrm{~kg} \mathrm{~K}_{2} \mathrm{O} \mathrm{ha}^{-1}$ which is statistically superior to the rest of the treatment under study. The lowest organic matter in post-harvest soil $(2.95 \%)$ was observed from $\mathrm{T}_{1}$ treatment with no fertilizers.

\subsubsection{Total nitrogen}

Total nitrogen in post-harvest soil showed statistically nonsignificant at different levels of NPK fertilizer for jhum cultivation (Table 5). The highest total nitrogen in post-harvest soil $(0.055 \%)$ was recorded from $\mathrm{T}_{4}$ treatment receiving 120 $\mathrm{kg} \mathrm{N}, 75 \mathrm{~kg} \mathrm{P}_{2} \mathrm{O}_{5}$ and $90 \mathrm{~kg} \mathrm{~K}_{2} \mathrm{O} \mathrm{ha}^{-1}$ and the lowest total nitrogen $(0.050 \%)$ was obtained from $\mathrm{T}_{1}$ treatment with no fertilizer.

\subsubsection{Available phosphorous}

A significant difference in available phosphorous content of post-harvest soil was observed at different levels of NPK fertilizers for jhum cultivation (Table 5). The highest available $\mathrm{P}(14.25 \mathrm{ppm})$ in the post-harvest soil was recorded in $\mathrm{T}_{4}$ treatment and the lowest available $\mathrm{P}(12.87 \mathrm{ppm})$ was noted in $\mathrm{T}_{1}$ (control) treatment.

\subsubsection{Exchangeable potassium}

Exchangeable potassium in post-harvest soil showed statistically non-significant at different levels of NPK fertilizer (Table 5). The maximum exchangeable potassium inpost-harvest soil $\left(0.73 \mathrm{meq} 100 \mathrm{~g}^{-1}\right.$ soil $)$ was found in $\mathrm{T}_{4}$ treatment received NPK@120:75:90 kg ha-1 which was superior to the rest of the treatment under study. The lowest available $\mathrm{K}\left(0.68 \mathrm{meq} 100 \mathrm{~g}^{-1}\right.$ soil $)$ was observed in $\mathrm{T}_{1}$ (control) treatment.

\subsubsection{Available sulphur}

A significant difference in available sulphur content of postharvest soil was observed at different levels of NPK fertilizers (Table 5). The highest available S (17.11 ppm) in the postharvest soil was recorded in $\mathrm{T}_{1}$ treatment received no fertilizer. The lowest available $\mathrm{S}(16.04 \mathrm{ppm})$ was found in $\mathrm{T}_{4}$ treatment received NPK@120:75:90 kg ha-1 which was statistically similar with $\mathrm{T}_{3}$ treatment.

Table 5: Effect of NPK fertilizers on $\mathrm{pH}$, organic matter, N, P, $\mathrm{K}$ and $\mathrm{S}$ content in post-harvest soil of jhum cultivation

\begin{tabular}{lcccccc}
\hline $\begin{array}{l}\text { Treat- } \\
\text { ment }\end{array}$ & $\begin{array}{c}\mathrm{pH} \\
\begin{array}{c}\text { Organic } \\
\text { matter } \\
(\%)\end{array}\end{array}$ & $\begin{array}{c}\text { Total } \\
\mathrm{N} \\
(\%)\end{array}$ & $\begin{array}{c}\text { Avail- } \\
\text { able P } \\
(\mathrm{ppm})\end{array}$ & $\begin{array}{c}\text { Exchange- } \\
\text { able K } \\
(\text { meq100 } \\
\left.\mathrm{g}^{-1} \text { soil }\right)\end{array}$ & $\begin{array}{c}\text { Avail- } \\
\text { able S } \\
(\mathrm{ppm})\end{array}$ \\
\hline $\mathrm{T}_{1}$ & 5.15 & 2.95 & 0.050 & $12.87^{\mathrm{b}}$ & 0.68 & $17.11^{\mathrm{a}}$ \\
$\mathrm{T}_{2}$ & 5.20 & 3.01 & 0.053 & $14.12^{\mathrm{a}}$ & 0.70 & $16.56^{\mathrm{b}}$ \\
$\mathrm{T}_{3}$ & 5.25 & 3.01 & 0.055 & $14.10^{\mathrm{a}}$ & 0.70 & $16.05^{\mathrm{c}}$ \\
$\mathrm{T}_{4}$ & 5.25 & 3.05 & 0.055 & $14.25^{\mathrm{a}}$ & 0.73 & $16.04^{\mathrm{c}}$ \\
$\mathrm{LSD}$ & $\mathrm{NS}$ & $\mathrm{NS}$ & $\mathrm{NS}$ & 0.48 & $\mathrm{NS}$ & 0.51 \\
$(p=0.05)$ & & & & & & \\
\hline
\end{tabular}

Means in a column followed by same letter (s) are not significantly different at $5 \%$ level of significance by LSD; $\mathrm{T}_{1}$ : No fertilizer (Control); $\mathrm{T}_{2}: 40 \mathrm{~kg} \mathrm{~N}+25 \mathrm{~kg} \mathrm{P}_{2} \mathrm{O}_{5}+30 \mathrm{~kg} \mathrm{~K}_{2} \mathrm{O} \mathrm{ha}^{-1} ; \mathrm{T}_{3}: 80 \mathrm{~kg} \mathrm{~N}+50$ $\mathrm{kg} \mathrm{P}_{2} \mathrm{O}_{5}+60 \mathrm{~kg} \mathrm{~K}_{2} \mathrm{O} \mathrm{ha}^{-1} ; \mathrm{T}_{4}: 120 \mathrm{~kg} \mathrm{~N}+75 \mathrm{~kg} \mathrm{P}_{2} \mathrm{O}_{5}+90 \mathrm{~kg} \mathrm{~K}_{2} \mathrm{O} \mathrm{ha}^{-1}$

\section{Conclusion}

Fertilizer had a significant effect on the yield characters of jhum crops. The application of $120 \mathrm{~kg} \mathrm{~N}+75 \mathrm{~kg} \mathrm{P}_{2} \mathrm{O}_{5}+90 \mathrm{~kg}$ $\mathrm{K}_{2} \mathrm{O} \mathrm{ha}^{-1}$ fertilizer was most favorable for improving yield and yield contributing characters of $j$ hum crops.

\section{Acknowledgement}

This research was supported by Krishi Gobeshona Foundation (KGF), Bangladesh. We are thankful to Krishi Gobeshona Foundation for their funding.

\section{References}

Abdel-Mawgoud, A.M.R., EL-Desuki, M., Salman, S.R., Hussein, S.D.A., 2005. Performance of some cucumber varieties as affected by different levels of mineral fertilizers. Journal of Agronomy 4, 242-247.

Alom, B., 2005. Effect of NPK alone and in combination on the growth and yield of pumpkin. Agricultural Research 
Station, Serai Naurang Bannu, NWFP, Pakistan 4(4), 428-431.

Borggaard, Ole, K., Gafur, A., Peterson, L., 2003. Sustainability appraisal of shifting cultivation in the Chittagong hill tracts of Bangladesh. Ambio 32(2), 118-123.

CARE (Cooperative for Assistance and Relief Everywhere) (2000). livelihood securityin the chittagong hill tracts: finding from a rural assessment. Dhaka, Bangladesh: CARE.

Farid, A.T.M., Iqbal, A., Karim, Z., 2009. Soil erosion in the Chittagong Hill Tract and its impact on nutrient status of soil. Bangladesh Journal of Soil Science 23, 92-101.

Gomez, K.A., Gomez, A.A., 1984. Statistical Procedures for Agricultural Research, $2^{\text {nd }}$ ed. (Chichester, UK: John Wiley and Sons).

Halim, M.S., Islam, N., Jahiruddin, M., 2004. Effects of NPK application on the performances of local and hybrid maize. Bangladesh Journal of Soil Science 26, 95-101.

Islam, M.A., Bari, M.A., Kunnaher, M.P., 2010. Effect of fertilizer on the growth, yield and grain nutrient concentration of $\mathrm{T}$. aman (Oryza sativa L.). Journal of Plant Nutrition 11(2), 41-52.

Kushwaha, B.L., 2001. Effect of nitrogen and potash on growth and yield of dwarf field pea. Indian Journal of Pulses Research 14(1), 44-47.

Makal, K.G., Joshi, A.T., Deshmukh, P.O., Pawar, P.R., 2007. Effect of N, P and $\mathrm{K}$ on tinda (Citrullus vulgaris var. fistulosus).The Orissa Journal of Horticulture 5(1/2), 62-63. [Cited from hort. Abst. 50(7), 5167, 1980]

Miah, M.M.U., Habibullah, P.B., Ali, M.F., 2008. Depletion of organic matter in upland soils of Bangladesh. In: Soil resilience and sustainable land use. In: Proceedings of international symposium, 28 Sept-2 Oct 2008, Budapest, Hungary.

Nmanop, S., 1997. Influences of nitrogen, phosphorus and potassium fertilizers on seed yield and seed quality of sweet gourd. Bull, Kasetsart Univ. Bangkok, Thailand, 711-729.

Nyalemegbe, K.K., Myers, R.J., Nandwa, S.M., 2009. Integrated fertilizer management for rice production on the vertisols of the accra plains of Ghana. West African Journal of Applied Ecology 32(3), 16-23.
Pachuri, D.C., Thakur, T.C., Verina, I.S., 2008. Effect of different levels of nitrogen, phosphorus and potash on seed yield of peas. Progressive Horticulture 20(1-12), $58-62$.

Rasul, G., Thapa, G.B., 2002. State plicies, praxies and land use in chittagong hill tracts of Bangladesh, regional and rural development planning, school of environment, resource and development, Asian Institute of Technology, Thailand, Bangkok.

Ravikumar, A.V., 2009. Effect of nitrogen phosphorus and potassiumon growth and yield of cucumber. Kamphaengsaen Academy Journal, 3, 18-29.

Ravi, S., Ramesh, S., Chandrasekaran, B., 2007. Influence of foliar application of phytohormones and nutrients on yield and nutrient uptake of transplanted rice in Annamalainagar, India. International Journal of Plant Sciences 2(1), 69-71.

Sandabe, A.K., Mishra, S.K., Sha, H.S., 2011. Response of summer sesame to row spacing and NPK. Orissa Journal of Agricultural Research 7, 99-101.

Satyanarayana, K.A., Tara, P., Murthy, V.R.K., Boote, K.J., 2010. Influence of integrated use of NPK fertilizers on yield and yield components of rainfed rice. Journal of Plant Nutrition 25(10), 200-209.

Talukder, M.K.H., Islam, M.S., Islam, S.M.N., 2011. Yield response of maize to different rates of phosphorus and potassium during the rabi season of Bangladesh. Bangladesh Journal of Soil Science 21, 69-74.

Ubeiz, I.G., 2009. Response of greenhouse cucumber to mineral fertilizers on a high phosphorus and potassium soil. Journal of Plant Nutrition 13, 269-273.

Uddin, M.J., Hassan, M.K., Miah, M.M., 2010. Identifying Livelihood patterns of ethnic minorities and their coping strategies different vulnerabilities situation in chittagong hill tracts region, bangladesh. final report, National food policy capacity strengthening programme food planning and monitoring unit (FPMU), Ministry of Food and Disaster Management. Government of Bangladesh, 53.

Ullah, M.M., Malek, M.A., Karim, M.M., Ali, M.S., 2012. A Report on Jhum Research in CHT. Hill Agriculture Research Station, BARI, Khagrachari. 